\title{
臓器虚血を伴う解離性大動脈瘤の治療経験
}

\author{
山内正信 中山健吾具光成 \\ 斉藤 雄 平野坂誠士
}

\begin{abstract}
当科で経験した臓器虚血を伴う解離性大動脈瘤手術症例 6 例について検討した. 年蹸は 52 73 歳, 平 均 62 歳で, DeBakey I 型 4 例, DeBakey III b 型 2 例(男女各 3 例)であった. 虚血臓器は, 脳十上 肢 1 例, 腸管+腎 1 例, 腎のみ 1 例, 腎十下肢 1 例, 下肢 2 例であった。手術は, DeBakey I 型の 4 例には上行または上行・弓部大動脈置換術を(うち 1 例で Y-グラフト置換術を追加), DeBakey III b 型の 2 例にはバイパス術と $\mathrm{Y}$-グラフト置換術を行った。 下肢虚血の 3 例のうち 2 例で MNMS (myonephropathic metabolic syndrome) を生じた. 結果は 6 例中 3 例が死亡と不良であった。蔵器 虚血を伴う解離性大動脈瘤に対しては, 術前の正確な診断(分枝の起始状況の把握) と適切な治療方針 が重要と思われた。 日心外会誌 25 巻 2 号 : 90-94 (1996)
\end{abstract}

Keywords : 解離性大動脈瘤, 臓器虚血, myonephropathic metabolic syndrome

\section{Clinical Experiences of Dissecting Aortic Aneurysm with Organ Ischemia}

Masanobu Yamauchi, Kengo Nakayama, Kousei Gu, Yuhei Saitoh and Seisi Nosaka (First Department of Surgery, Shimane Medical University, Izumo, Japan)

We studied 6 surgical cases of dissecting aortic aneurysm with organ ischemia, consisting of 4 cases of DeBakey type I dissection and 2 cases of DeBakey type III b dissection and the average age was 62 years old. The ischemic organs were, the brain and upper extrimities, intestine and kidney, kidney, kidney and lower extrimity, and bilateral lower extremities, respectively. We performed the graft replacements of the ascending aorta or ascending aorta and arch for DeBakey type I dissection, and bypass or Y-graft replacement for DeBakey type III b dissection. In one case of DeBakey type I dissection we performed a second Y-graft replacement two days after the first operation. MNMS (myonephropathic metabolic syndrome) developed in two cases of 3 lower extremity ischemia. The results were unsatisfactory because 3 patients died. To improve of the outcome of surgical treatment in case of dissecting aortic aneurysm with organ ischemia, preoperative appropriate diagnosis and appropriate surgical planning are necessary. Jpn. J. Cardiovasc. Surg. 25 : 90-94 (1996)

解離性大動脈瘤は破裂の危険性のみならず，解 離に基づく臟器虚血も問題になる．臓器虚血を合 併した場合，虚血症状が前面に現れるため，解離 の存在を見落としたり，また診断がついたとして も，その治療方針，術式については種々の方法が 考えられ，各施設で異なった方法がとられている のが現状である．今回当科で経験した臟器虚血を 伴う解離性大動脈瘤手術症例について検討したの で報告する。

\section{対 象}

過去 10 年間に当科で経験した解離性大動脈瘤

1995 年 3 月 6 日受付， 1995 年 6 月 21 日採用

島根医科大学第 1 外科 $\mathbf{T} 693$ 出雲市塩冶町 89-1
は 26 例でこのうち臟器虚血を呈したものは 6 例 であった。

DeBakey I 型 4 例, DeBakey III b 型 2 例で男 3 例, 女 3 例であった. 年齢は 52 ～73 歳, 平均 62 歳であった。臓器虚血は, 脳十上肢 1 例, 腸管十 腎 1 例，腎のみ 1 例，腎 + 下肢 1 例，下肢のみ 2 例であった(表 1 )。

\section{症例}

症例 1 は 55 歳の女性で突然の背部, 上腹部痛で 発症した。CT 上は上行大動脈から腎動脈レベル の腹部大動脈までの早期血栓閉鎖型解離性大動脈 瘤のため，内科的降圧療法の方針としたが，翌日 突然ショック状態となり，意識障害と右上肢の虚 
表 1

\begin{tabular}{|c|c|c|c|c|c|c|}
\hline 症例 & 年齢/性 & 解離型 & 真腔から起始しない枝 & 虚血臟器 & 手術術式 & 結果 \\
\hline 1 & $55 / \mathrm{F}$ & DeBakey I 型 & r-SCA & 脳, 右上肢 & 上行・弓部大動脈置換術 & $\begin{array}{l}\text { 死亡 } \\
\text { (6 口後) }\end{array}$ \\
\hline 2 & $73 / \mathrm{F}$ & DeBakey I 型 & $\begin{array}{l}\text { BCA, bil.-SCA, CA, } \\
\text { SMA, IMA, I-RA, } \\
\text { bil.-IA }\end{array}$ & 腸，腎 & 上行大動脈置換術 & $\begin{array}{l}\text { 死亡 } \\
\text { (術死) }\end{array}$ \\
\hline 3 & $70 / \mathrm{F}$ & DeBakey I 型 & CA, I-RA & 腎 & 上行大動脈置換術 & 生存 \\
\hline 4 & $52 / \mathrm{M}$ & DeBakey I 型 & なし & 腎，両下肢 & $\begin{array}{l}\text { 上行・弓部大動脈置換術, } \\
\mathrm{Y} \text {-グラント置換術 }\end{array}$ & 生存 \\
\hline 5 & $61 / \mathrm{M}$ & DeBakey IIIb 型 & I-IA & 両下肢 & $\begin{array}{l}\text { 上行大動脈-両大腿動脈バ } \\
\text { イパス術 }\end{array}$ & $\begin{array}{c}\text { 死亡 } \\
\text { (14日後) }\end{array}$ \\
\hline 6 & $62 / \mathrm{M}$ & DeBakey IIIb 型 & bil.-IA & 両下肢 & Y-グラフト置換術 & 生存 \\
\hline
\end{tabular}

$\mathrm{F}$ ：女性, $\mathrm{M}$ ：男性, $\mathrm{r}-\mathrm{SCA}$ ：右鎖骨下動脈, BCA：腕頭動脈, bil.-SCA：両側鎖骨下動脈, CA：腹腔動脈, SMA： 上腸間膜動脈，IMA：下腸間膜動脈，1-RA：左腎動脈，1-IA：腸骨動脈左，bil.-IA：両側腸骨動脈。

血を認めた。CT, DSA にて上行大動脈から下行大 動脈にかけて解離腔に血流を認め，右鎖骨下動脈 は閉塞していた。上肢虚血に対して右腋窩動脈か ら血栓除去を行い血流を再開した後，上行・弓部 大動脈置換㧍よび 3 分枝再建術を行ったが，術後 広汎な脳梗塞のため 1 週後に死亡した。脳梗塞の 原因は術前のショックのためか術中の脳への低灌 流のためか不明であった。

症例 2 は 73 歳女性で DeBakey I 型の急性解 離で緊急で上行大動脈置換術を行ったが，術中死 した。剖検にて腕頭動脈，左右鎖骨下動脈，腹腔 動脈，上・下腸間膜動脈，左腎動脈，左右腸骨動 脈には解離が及び，心筋内血腫，小腸・大腸壊死， 左腎梗塞，左右腸骨動脈閉塞を認めた。大動脈は 前壁を残し $3 / 4$ 周が解離し，上腸間膜動脈は約 12 $\mathrm{cm}$ にわたって起始部から解離し，広沉な小腸・大 腸壊死をおこし，救命は困難な症例と思われた。

症例 3 は 70 歳女性で DeBakey I 型の慢性解 離である。血管造影でリエントリーは左総腸骨動 脈に認め, 腹腔動脈，左腎動脈は解離腔から起始 し(図 1 左)，レノグラムで左腎機能低下を認めた (図 1 右上)。予定術式としては，上行・弓部大動 脈置換術で末梢側吻合は double barrel に吻合す るつもりであったが，術中所見で下行大動脈の外 膜が脆弱で double barrel は危険と判断し，弓部
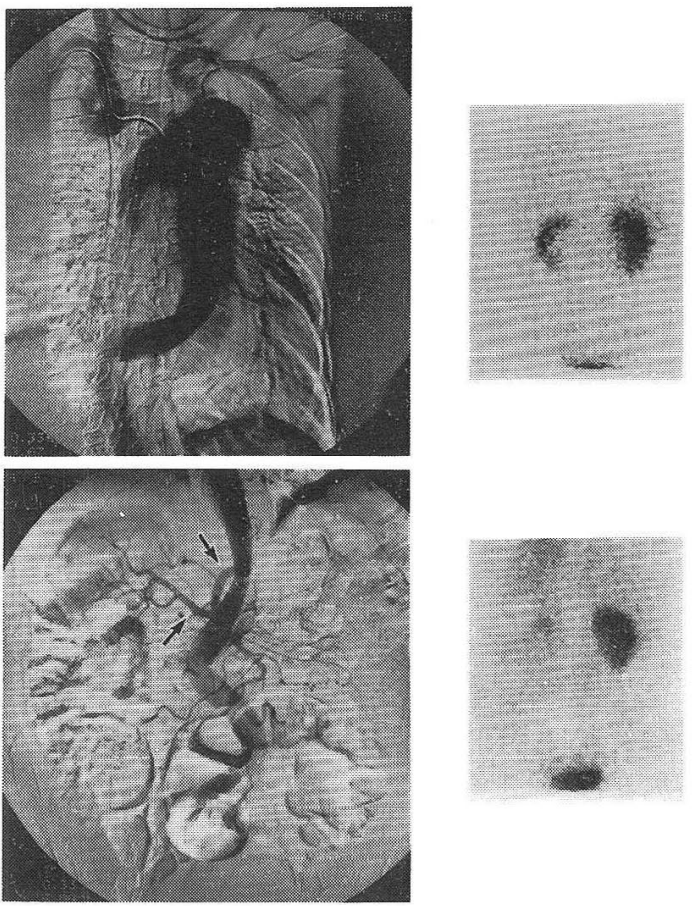

図 1

(左) 術前 DSA。真腔から SMA, r-RAのみ造影されて いる $(\rightarrow)$. (右上)術前レノグラム。(右下)術後レノグ ラム。

の解離腔を $\mathrm{GRF}$ 糊で閉鎖し，上行大動脈置換術 のみを行った。術後腎不全となったが，持続血液 濾過，腹膜透析を約 1 か月施行した後離脱でき， 

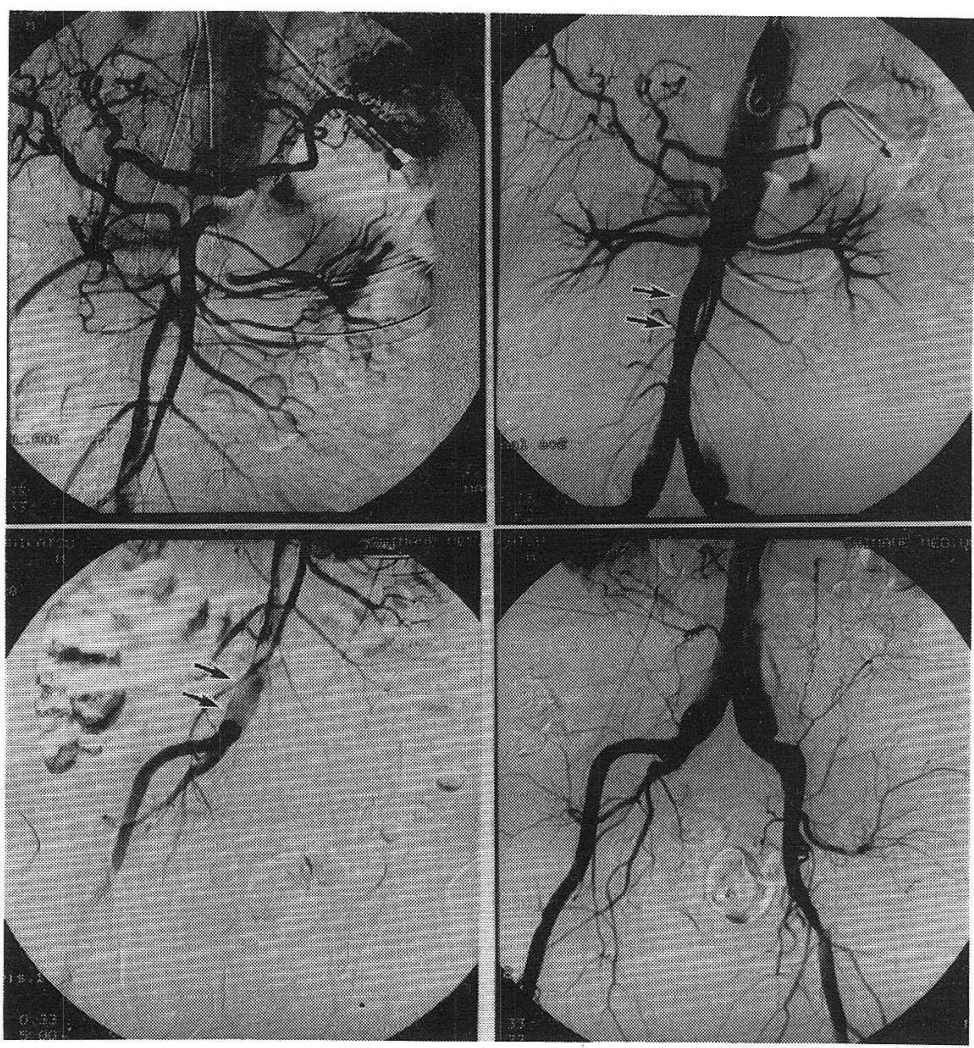

図 2 術後第 1 病日 DSA

第 1 回目 (左). 真腔の閉塞を認める $(\rightarrow)$. 第 2 回目 (10 分後) (右)。真腔の再開通を 認める $(\rightarrow)$.

9 か月後に退院した。術後 $\mathrm{CT}$ 上左腎萎縮を認め, レノグラムでも無機能腎であったが(図 1 右下), 24 時間クレアチニンクリアランスは $61 l /$ day と 回復していた。また術後危惧された肝機能の悪化 はみられなかった。

症例 4 は 52 歳の男性でDeBakey I 型の慢性 解離に対し上行・弓部大動脈置換および 3 分枝再 建術を行った。翌日突然の無尿と両下肢のチア， ーゼが出現したため, DSAを行った。1回目の DSA では腎動脈レベルの腹部大動脈真腔の閉塞 を(図 2 左), 10 分後の 2 回目の DSA では真腔の 再開通を認めた (図 2 右)。DSA 後いったん症状が 良くなったため経過観察としたが, 再び症状が再 発したため緊急で腎動脈下 $\mathrm{Y}$-グラフト置換術を 行った。術後下肢虚血によるミオグロビン尿, 腎 不全状態となったが，4 か月後に軽快退院した。

症例 5 は 61 歳男性で突然の左下肢のチアノー
ゼに対し，左総腸骨動脈から左浅大腿動脈の血栓 除去を行い，いつたん回復したが，2 日後再び両 下肢のチアノーゼ, 疼痛を呈した。CT 上 DeBakey III b 型解離を認めた。上行大動脈一両大腿動 脈バイパス術を行ったが，術後 MNMS (myonephropathic metabolic syndrome)による腎不全 のため死亡した。

症例 6 は 62 歳男性で DeBakey III b 型解離で, 血管造影で右総腸骨動脈, 左外腸骨動脈の閉塞を 認めた。下行大動脈の最大径は $3 \mathrm{~cm}$ と拡大は軽 度であったが，両下肢の虚血症状が改善しないた め, 発症から 20 日後に腎動脈下で $\mathrm{Y}$-グラフト置 換術(中枢側を double barrel に吻合)を行った。 術後軽い腎不全となったが軽快し， 3 か月後に退 院した。 


\section{考察}

臓器虚血を伴う解離性大動脈瘤は重篤で，迅速 な対処が望まれる.この問題は第 21 回日本心臓血 管外科学会学術総会のシンポジウムで取り上げら れている ${ }^{1 \sim 12)}$.このなかの 12 施設の約 800 例の解 離性大動脈瘤のうち 77 例が臓器虚血を呈してい た (約 10\%). 虚血臓器は, 心臓 20 例 (11.3\%), 脳 40 例 $(22.6 \%)$, 脊髄 10 例 $(5.6 \%)$, 肺 1 例 $(0.6 \%)$, 肝 4 例 (2.3\%), 腸 23 例 (13.0\%), 腎 42 例 (23.7\%), 上肢 3 例 (1.7\%), 下肢 77 例 $(43.5 \%)$ で下肢, 腎, 脳, 腸, 心臟の順に多かった。死亡 率は腸 $(73.7 \%)$ ，心臓(66.7\%)，肝 $(66.7 \%)$ ，腎 $(36.8 \%)$, 脳 $(33.3 \%)$, 下肢 $(32.7 \%)$ で高く，診 断の遅れや治療の困難さを示している。一方脊髄 虚血は致命的な合併症ではないが(死亡率 $11.1 \%)$, 術後回復のみられないものが多かった. 診断については, 胸部 X 線, 造影 CT で解離性 大動脈瘤と診断できれば可能な限り血管造影を行 い，エントリー，リエントリーの位置と各分枝の 起始状況を術前に把握しておくことが必要と思わ れる。とくに腸管および心臟虚血は，死亡率が高 いので，より早期の対応が望まれる。この点に関 し高本ら ${ }^{13)}$ は, 術中 minilaparotomy を行い, 腹 部主要分枝血流をドプラー断層法で調べ，必要で あれば fenestration を行って，血流を確保し救命 せしめ，その有用性を報告している。

当科での結果をふまえ，各臟器ごとの治療方針 を考えた。1)心臓虚血：冠動脈に解離が及ぶ場合 は，冠動脈バイパスが必要である。しかし心筋内 にも解離が及び血腫を形成したり，血流再開まで に時間を要して梗塞となったりして, 結果は必ず しも良くない，2)脳虚血：可逆性の脳障害の場合 (一過性の意識消失, CT で脳梗塞のないもの)に は大動脈置換術，分枝再建術等を積極的にすべき であるが，coma 症例や脳梗塞の明らかな例では 急性期手術は適応外と思われる，3)肝虚血・腸管 虚血：DeBakey I 型に対してはまず解離に対す る手術を行った後, 腸管壊死が疑われれば(原因不 明のアシドーシス等)緊急試験開腹術を行い, fenestration $^{13)}$ や腸切除 ${ }^{3)}$ を行う。しかし急性例 では診断が遅れたり，また診断がついても致命的
な場合が多い. DeBakey III b 型に対しては fenestration ${ }^{13)}$ が有効と思われる。4)腎虚血： DeBakey I 型に対してはまず解離に対する手術 を行う。片側の腎動脈が解離腔から起始していて も，術後リエントリーがエントリーとなって腎血 流は確保されるという報告もあり ${ }^{14)}$ ，長期的には 回復する場合が多い. DeBakey III b 型に対して は fenestration や腎自家移植 ${ }^{15)}$ を考慮する。腹部 主要分枝の虚血の場合，大動脈置換の末梢側吻合 を double barrel に行う方法もあるが16)，この場 合術後に解離腔の拡大や破裂する危険があるので 真腔が非常に細い場合以外は適応がないと思われ る。5）上・下肢虚血：DeBakey I 型では解離に対 する手術を行い真腔血流を増加させた後，虚血に 対する手術を行う。DeBakey III b 型では虚血に 対する手術(バイパス術，fenestration)を行った 後，降圧療法を行う。両下肢虚血では MNMS に 対する注意が必要である。

\section{ま と め}

当科で経験した臓器虚血を伴う解離性大動脈瘤 手術症例 6 例について検討した。結果は 6 例中 3 例が死亡と不良で, 術前の正確な診断と適切な治 療方針が重要と思われた。

\section{文献}

1）高橋隆一，川田光三，四津良平ほか：臟器阻血を 伴う急性大動脈解離の外科. 日心外会誌 20 (Suppl.) : 104, 1991.

2) 内田發三，寺本 滋：臟器虚血を伴う解離性大動 脈瘤の臨床像と治療成績.日心外会誌 20 (Suppl.) : 104, 1991.

3）安達秀雄, 許 俊鋭, 木村壮介ほか：臟器阻血を 伴う急性大動脈解離の外科 - - 早期の血行再建術 の重要性. 日心外会誌 20(Suppl.)：105, 1991.

4）平山統一, 青見茂之, 橋本明政ほか：臓器阻血を 伴う急性大動脈解離の外科一手術術式および循 環補助方法の選択. 日心外会誌 20 (Suppl.)：105, 1991.

5）伊藤 翼, 夏秋正文, 橒木 等ほか：急性 $\mathrm{A}$ 型大 動脈解離の急性期手術一大動脈分枝閉塞の及ぼ す影響一。目心外会誌 20(Suppl.)：106, 1991.

6) 小澤修一, 岡田昌義, 山本信一郎ほか: 臟器阻血 を伴う急性大動脈解離に対する外科治療. 日心外 会誌 20 (Suppl.)：106, 1991.

7）山里有男, 花田正治, 神野君夫ほか：臟器阻血を 
ともなう急性大動脈解離の外科. 日心外会誌 20 (Suppl.): 107, 1991.

8）安達盛次, 中島伸之, 安藤太三ほか：臓器虚血を 伴う大動脈解離の外科. 日心外会誌 20 (Suppl.)： 107, 1991

9）数井暉久, 稲岡正巳, 山田 修ほか：臓器阻血を 伴う急性大動脈解離例に対する外科治療の問題 点. 日心外会誌 20(Suppl.)：108, 1991.

10）上山武史，湖東慶樹，明元克司ほか：急性大動脈 解離時の血清 Creatine Kinase 值変動より見た 臓器阻血とその手術対策. 日心外会誌 20 (Suppl.): 108, 1991.

11）有泉憲史，小出司郎策，小田桐重遠ほか：蔵器虚 血を合併した急性大動脈解離の対策.日心外会誌 20 (Suppl.) : 130, 1991.

12) 田辺貞雄, 山田崇之, 中原秀樹ほか : 臓器阻血を 伴う急性大動脈の解離の外科一虚血の機序と予
後の関係。日心外会誌 20 (Suppl.)：130, 1991.

13）高本眞一, 安藤太三, 大北 裕ほか：経食道なら びに術中ドプラー断層による解離性大動脈瘤内 血流動態把握に基づいた治療.日心外会誌 24 (Suppl.) : 88, 1995.

14）玉木修治, 中島伸之, 川副浩平ほか：解離性大動 脈瘤手術前後の腎機能および手術方法の検討一 偽腔により潅流されていた腎の術後血流，機能の 変化について一. 日胸外会誌 $37: 1179-1186$, 1989.

15）高橋章之, 佐藤伸一, 中井一郎ほか：解離性大動 脈瘤における腎自家移植の検討.日心外会誌 23 (Suppl.) : 227, 1994.

16）北村惣一郎, 井上 毅：Stanford $\mathrm{A}$ 型解離の外 科治療, 大動脈解離。病理・診断・治療。阿部稔 雄編, 初版, 名古屋大学出版会, 名古屋, 1992, pp. 111-113. 